\title{
SPECIAL ECONOMIC ZONE AS INNOVATION BOOSTER IN LESS DEVELOPED REGIONS
}

Dace Ziedina ${ }^{1}$, Mg.oec.; Modrite Pelse ${ }^{2}$, Dr.oec., professor

1,2Latvia University of Life Sciences and Technologies; Faculty of Economics and Social Development

Abstract. Based on statistical data about financial indicators in the regions of Latvia, there can be observed a general finding that economic situation in the regions of Latvia is improving. But at the same time regional disparities between regions still remain. To decrease regional disparities, a variety of regional development instruments are used in Latvia. One of them is a special economic zone, which should be established in less developed regions. To operate in a special economic zone, companies should make investments in their business, primarily in fixed assets. The authors of research paper have discussed whether a special economic zone may be considered as an innovation booster in less developed regions. By using descriptive methods, the authors described economic situation in the regions of Latvia, defined main measure points of innovation level in regional aspect and analysed examples of innovative companies in special economic zones. The authors concluded, that if special economic zones play a role as innovation booster in less developed regions, than companies which operate in a special economic zone should primarily focus on investments in technology as innovation agent.

Key words: innovation; regional development; special economic zone, investment.

JEL code: O31; R11; F21.

\section{Introduction}

For the past years, statistic data shows that economic situation in the regions of Latvia is changing rapidly. Gross domestic product (hereafter - GDP) in statistical regions during the period of 15 years has grown more than four times on average. According to economic trends in the regions of Latvia, the gap in GDP per capita between the richest region (Riga) and less developed region (Latgale) has decreased, but at the same time Latvia remains the country with $9^{\text {th }}$ highest regional disparities between regions (in the Organization for Economic Co-operation and Development countries (hereafter - OECD)) (Regions and Cities..., 2018).

Variety of regional development instruments are used in the regions of Latvia to improve their socio-economic situation and one of such instruments is establishment of special economic zones with an aim to attract investments and create new job places. A special economic zone can attract foreign and local investment, promote export-oriented growth and generate employment (Special economic zones..., 2018). Particularly special economic zones in Latvia (in total five) are established in less developed regions (two special economic zones are located in Latgale region) and in welldeveloped regions as Kurzeme and Riga, where two free ports and one special economic zone operate. This fact leads to assumption that a special economic zone can work as an agent of innovation booster especially in less developed regions.

The aim of the research paper is to examine whether a special economic zone can boost innovation in less developed regions. To achieve the aim, the following tasks were set:

1) to describe the economic situation in the regions of Latvia;

2) to define the measure points of innovation level in a regional aspect;

3) to analyse Latvia's experience in special economic zones as innovation booster in less developed regions.

The descriptive methods mainly (analysis and synthesis) were used in the research; the novelty of which is description of examples according to innovation intensive investment projects in special economic zones. 


\section{Research results and discussion}

Heretofore the authors of the research paper start a discussion on the linkage between special economic zones and innovation, it is necessity to understand the background of economic situation in the regions of Latvia in the time period from 2000 to 2016. As shown in the Table 1, the GDP in Latvia during the period from 2000 to 2016 has increased 4.4 times.

Table 1

\section{Gross domestic product in statistical regions of Latvia, in 2000-2016} (per one inhabitant, EUR)

\begin{tabular}{|l|l|c|c|c|c|c|c|}
\hline No & \multicolumn{1}{|c|}{ Region of Latvia } & $\mathbf{2 0 0 0 .}$ & $\mathbf{2 0 0 1 .}$ & $\mathbf{2 0 1 4 .}$ & $\mathbf{2 0 1 5 .}$ & $\mathbf{2 0 1 6 .}$ & $\begin{array}{c}\text { Increase, } \\
\text { times }\end{array}$ \\
\hline 1. & Riga* region & 4849 & 5419 & 19739 & 20523 & 21078 & 4.3 \\
\hline 2. & Pieriga region & 2256 & 2431 & 9375 & 9830 & 10445 & 4.6 \\
\hline 3. & Vidzeme region & 1787 & 1980 & 7944 & 8050 & 8404 & 4.7 \\
\hline 4. & Kurzeme region & 2559 & 2822 & 8892 & 9035 & 9505 & 3.7 \\
\hline $\mathbf{5 .}$ & Zemgale region & 1826 & 1942 & 7518 & 7825 & 8046 & 4.4 \\
\hline 6. & Latgale region & 1424 & 1558 & 6183 & 6375 & 6516 & 4.6 \\
\hline
\end{tabular}

*Riga region - as a region of the capital city.

Source: author's calculations based on the data of the Central Statistical Bureau of Latvia

Looking form the perspective of regions, the major increase in regional GDP is observed in Vidzeme region ( 4.7 times), followed by Pieriga region and Latgale region (each 4.6 times). Despite the rapid growth, GDP in Latgale region still lags behind other regions of Latvia. At the same time, specific regional development instruments such as special economic zones are available in Latgale region, which leads to the question - how special economic zones can boost innovations in less developed regions.

Regarding the above mentioned, the economists do not have consensus on the following contrasting suppositions:

a) it is impossible to capture the benefits of innovation within GDP (Coyle D., 2017);

b) economic growth can be slower when innovation accelerates, because of the fact that productivity depends also on the increase of physical and human capital (Gordon R.J., 2018);

c) innovation is the key driving force behind regional economic growth, standards of living and international competitiveness (Acs Z.J, et al, 2002).

Responding to first supposition (a)), the authors have defined few measure points of innovation level in a regional aspect by using the statistical data available at the regional level. Authors claim that the main problem why it is impossible to capture benefits of innovation within GDP is a lack of statistical data and probably - composition of GDP should be reviewed with aim to capture economic growth from innovation. Regarding the second supposition (b)), it should be mentioned that economic growth can shrink due to the influence of innovation, e.g. resulting in a smaller number of job places needed to serve companies and business. Regarding the third supposition (c)), the European Central Bank claims that innovation can lead to higher productivity as the same input generates superior output in a business area - when productivity raises, more goods and services are produced (How does innovation..., 2017).

\section{Measure points of innovation level in regional aspect}

European Innovation Scoreboard 2018 (European Innovation Scoreboard..., 2018), which evaluates innovation development indicators in the European Union Member States and is adapted by the European Commission, measures performance of innovation systems by average performance 
on 27 indicators such as human resources, attractive research systems, as well as innovation-friendly environment etc. European Innovation Scoreboard ranks Latvia among the group "Moderate innovator". The group of Moderate Innovators includes those Member States where innovation performance is between $50 \%$ and $90 \%$ of the EU average - a Croatia, Cyprus, the Czech Republic, Estonia, Greece, Hungary, Italy, Latvia, Lithuania, Malta, Poland, Portugal, Slovakia, and Spain. The highest possible value of index is 100. According to the data of European Innovation Scoreboard 2018 , the score of Latvia is $43.18 \%$. Latvia's overall performance tends to improve, ranking Latvia in 34th place (score for year 2017). Latvia has the strongest performance in "innovation-friendly environment" and in "finance and support" dimensions. Thus, "innovators" and "firm investments" are the weakest innovation dimensions.

There is a lack of regional level statistical data to evaluate innovation level in the regions of Latvia. The authors of this research paper consider that innovation level in the regions of Latvia can be observed by such groups of indicators as:

- human capital (population by age groups; level of education; number of educational institutions);

- financial indicators (economically active statistical units of the market sector per 1000 inhabitants, non-financial investments per one inhabitant, total sum of direct foreign investment per 1000 inhabitants).

The European Commission's 2014 Regional Innovation Scoreboard found that better circumstances for entrepreneurship and innovation are in those regions where inhabitants show more positive attitude towards new things and ideas. Such a statement leads to the fact that young people have more positive attitude towards new things and ideas. According to the data of the Regional development indicators module, the highest number of population in the analysed age group (from 15 to 61 years) is in Latgale region (62.8\% of total population, year 2018), followed by Zemgale and Vidzeme regions (each $62.5 \%$ of total population in 2018).

Education level is one of the indicators which can describe human capital in the prism of innovation. The aggregated results of the Central Statistical Bureau (of Latvia) in 2011 on Population and Housing Census lead to the conclusion that people with a higher level of education are concentrated in densely populated areas. Accordingly, $62.4 \%$ of the total population in Riga region are inhabitants with higher education, including doctor degree holders. Specific situation was demonstrated by Latgale region, where $40.9 \%$ of the total population are inhabitants with vocational secondary education or vocational education. Education level in other regions of Latvia reveals more or less proportional distribution of education levels, including secondary education. Academic researchers and policymakers consider that education leads to growing numbers of innovation and that the number of innovation or inventors can be increased though educational policy (Does education lead..., 2013). The authors consider that in a region with lower level of education it would be more difficult to introduce and implement innovation than in the regions with population that have relevant higher education level. In such situation one of possible solutions could be to strengthen innovation capability within secondary education.

The Innovation Strategy of the OECD provides that education systems are essential for innovation by developing skills, promoting new ideas and technologies (Education and Skills, s.a.). It is most often assumed that higher education institutions are the main stage of education where understanding and innovation abilities of students (future inhabitants in giving age) are promoted; however, attention should also be paid to other levels of education. In 2018, there were 847 educational institutions in Riga region (from them 44 higher education institutions), followed by 
Latgale region with 125 educational institutions (from them five were higher education institutions). Three higher education institutions were in Kurzeme region, two in Zemgale region, and only one in Vidzeme region.

Financial indicators. Component of GDP - „investment by spendings in business" indirectly can show the impact of innovation process, whether economic situation is improving. It should be taken into account that innovation is not as simple as spending more money in technologies. Innovation process includes reallocation of available resources and agile planning process. Researchers state that innovation and spending in research and development can enhance the growth of economy and can be a driver of sustainable development (Fernandez Fernandez Y., et.al, 2018).

The indicator which demonstrates non-financial investments per capita indirectly can show the impact of innovation as well. According to the data revealed in the Table 2, the lowest non-financial investments per capita are in Latgale region, while Riga region takes the lead by five times higher (year 2017) value of this indicator. Non-financial investments can include specific investments in innovations, thus the lowest rate in less developed regions should be stipulated with specific regional development instruments such as special economic zones.

Table 2

\section{Financial indicators in the regions of Latvia, in 2015 and 2017} (per capita, EUR)

\begin{tabular}{|l|l|c|c|c|c|c|c|}
\hline No & Region of Latvia & $\mathbf{2 0 1 5}$ & $\mathbf{2 0 1 7}$ & $\mathbf{2 0 1 5}$ & $\mathbf{2 0 1 7}$ & $\mathbf{2 0 1 5}$ & $\mathbf{2 0 1 7}$ \\
\hline 0. & Financial indicators & $\begin{array}{c}\text { Economically active } \\
\text { statistical units of } \\
\text { the market sector } \\
\text { per 1000 } \\
\text { inhabitants, number }\end{array}$ & \multicolumn{2}{|c|}{$\begin{array}{c}\text { Non-financial } \\
\text { investments per } \\
\text { capita, EUR }\end{array}$} & \multicolumn{2}{|c|}{$\begin{array}{c}\text { Total sum of direct foreign } \\
\text { investment per } 1000 \\
\text { inhabitants, EUR }\end{array}$} \\
\hline 1. & Riga region & 91.98 & 93.42 & 3188.65 & 2974.89 & 1880567.76 & 1452781.19 \\
\hline 3. & Vidzeme region & 76.37 & 79.83 & 1096.54 & 1161.02 & 469875.80 & 77077.66 \\
\hline 4. & Kurzeme region & 67.97 & 73.86 & 1376.98 & 1118.88 & 485785.92 & 480803.52 \\
\hline 5. & Zemgale region & 61.52 & 63.33 & 1006.93 & 1128.64 & 173110.70 & 164272.16 \\
\hline 6. & Latgale region & 61.86 & 61.24 & 683.15 & 610.67 & 82294.29 & 65969.57 \\
\hline
\end{tabular}

Source: author's calculations based on the data of Regional development indicators' module

The trend of non-financial investments and direct foreign investment shows that in a period of 2015 to 2017, these indicators decreased, which confirms the before mentioned supposition that economic growth can be slower when innovation accelerates. At the same time, the authors cannot confirm the assumption that the decrease of these financial indicators was caused by direct influence from innovation.

The indicator which increased during the period of 2015 to 2017, is the number of economically active statistical units of the market sector. According to the specific features of regional statistics, it is problematic to evaluate whether economically active statistical unit of market sector is innovative. The growth of this indicator gives evidence of higher competition in the market between different economically active statistical units, where is a possibility of innovation growth.

\section{Latvia's experience in special economic zones as innovation booster in less developed regions}

The European Parliament's Committee on Regional Development stresses that innovation can be most effectively addressed at regional level, where physical proximity can encourage partnerships between such actors as universities, research organizations, companies and regional, local authorities (Opinion of the..., 2011). This report points out that the most dynamic technology sectors are not 
always present in or near urban municipalities, but close to the most innovative universities. The Committee on Regional Development calls all regions to invest in innovation and to adapt regional innovation strategies in order to increase their efficiency and as well to rejuvenate human capital and to increase the capacity of companies to innovate.

In case of Latvia, there are two special economic zones in less developed region (Latgale) - Latgale special economic zone and Rezekne special economic zone. The existing aid mechanism in special economic zones of Latvia does not focus on innovation, it primarily motivates investment intensive projects only in fixed assets, thus the innovation aspect in modern technologies usually is secondary.

\section{Rezekne special zone investment projects (13 projects)}

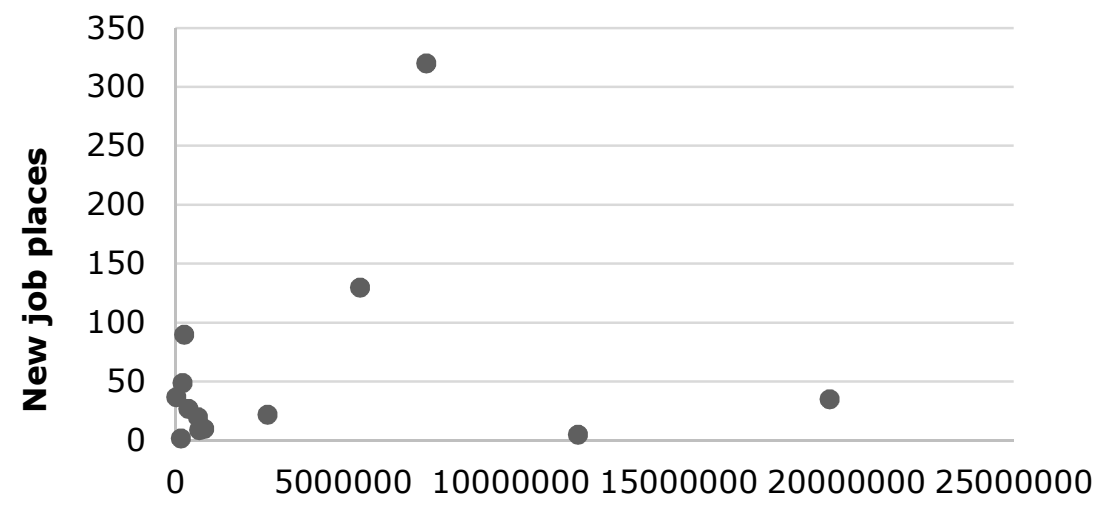

Investment, EUR

Source: author's calculations based on the data of the Ministry of Environmental Protection and Regional Development

Fig. 1. Linkage between amount of investment (EUR) per new workplaces created in Rezekne special economic zone

As Figure 1 demonstrates, from 13 projects (shown as example without implementation year) the authors have highlighted two investment projects, where investment per one new workplace is noticeably higher than in other projects. The first project with investment amount of 12000000 EUR creates only five new workplaces (2 400000 EUR of investment per one new workplace). The second project with investment amount of 19513100 EUR creates 35 new workplaces (557 517 EUR of investment per one new workplace). It can be considered that usually innovative investment projects have an impact on technologies, thus new workplaces which are created within the project are secondary. The authors agree on that, based on project examples form Rezekne special economic zone. In most of cases the companies which operate in special economic zone do not concentrate on innovation because the profile of these companies is woodworking, metal working, production of beverages, production of textiles etc. (Investors, s.a.). Such entrepreneurship profiles according to the data in Figure 1 make low investments per one new workplace -while another project with investment amount of only 27000 EUR creates 37 new workplaces (730 EUR of investment per one new job place). At the same time, in the special economic zone also companies with such profile as production of fiberglass products operate and their manufacturing process in its turn demands to ensure research and development progress to increase productivity.

Examples of innovative investment projects in special economic zones of Latvia (in less developed regions). The authors observed few innovative projects among the applicants intending to acquire status of special economic zone. In 2018, the status of Rezekne special economic zone was assigned to the company "RSEZ SIA FLORAPLANET" that provides an electronic trading platform 
for agricultural plant manufacturers. Such technologies demand high investment amount to ensure development of information technologies which are used in the company "RSEZ SIA FLORAPLANET". The site or electronic trading platform is still in the process, but flowers and plants from many European suppliers are already available to Russian consumers.

The company "RSEZ SIA LEAX Rezekne" ensures serial metal processing services as production of parts for automotive, mining and machine production industries. To satisfy the demand of the leading automotive customers, the company pays special attention to upgrading production processes. It can be implemented within cooperation in research and development area involving customers, higher education institutions, local municipality and special economic zones.

In Latgale special economic zone, the company SIA "LIGHT GUIDE OPTICS INTERNATIONAL" operates, which is one of the world's largest optical fibre producers. Since y 2013, the company's research department has developed new products and production technologies, thus acquiring the world's most advanced industry technologies with high staff qualification.

\section{Conclusions and proposals}

1) Economic development trends in the regions of Latvia demonstrate that there is a possibility to boost innovations in less developed regions, which certifies the fact that better circumstances for innovation are available in the regions where inhabitants (young generation) have more positive attitude towards new things and ideas.

2) The existing aid mechanism in special economic zones of Latvia does not focus on innovation, it primarily motivates investment intensive projects only in fixed assets, thus the innovation aspect in modern technologies usually is secondary.

3) Since special economic zones play a role as innovation booster in less developed regions, those businesses that operate in a special economic zone should primarily focus on technology as innovation agent.

4) Most of companies which operate in a special economic zone do not concentrate on innovation because of their companies' profile (woodworking, metal working, production of beverages, production of textiles, etc.), which does not require specific solutions to increase productivity.

5) As a proposal, the authors suggest that the state aid in the form of decreased corporate income tax should be given within those investment projects, which increase innovation level in the company which operates in a special economic zone.

\section{Bibliography}

1. European Innovation Scoreboard (2018). Retrieved: https://ec.europa.eu/growth/industry/innovation/factsfigures/scoreboards_en Access: 01.02.2019.

2. Innovation Strategy (2010). Retrieved: https://www.oecd.org/site/innovationstrategy/ Access: 01.02.2019.

3. Special Economic Zones: challenges and opportunities (2018). Retrieved: https://worldinvestmentforum.unctad.org/session/free-special-economic-zones-challenges-andopportunities/ Access: 06.02.2019.

4. How Does Innovation Lead To Growth? (2017). Retrieved: https://www.ecb.europa.eu/explainers/tell-memore/html/growth.en.html Access: 07.02.2019.

5. Does Education Lead To More Innovation? (2013). Retrieved: https://voxeu.org/article/does-educationlead-more-innovation-0 Access: 07.02.2019.

6. Fernandez Fernández, Y., Fernandez Lopez, M.A., Olmedillas Blanco, B. (2018). Innovation For Sustainability: The Impact Of R\&D Spending On CO2 Emissions. Journal of Cleaner Production, Volume 172, p.3459-3467.

7. Coyle, D. (2017). Rethinking GDP. Finance \& Development, Volume 54, No.1, p. 16-19.

8. Gordon, R.J. (2018). Why Has Economic Growth Slowed When Innovation Appears To Be Accelerating? National Bureau of Economic Research, Working paper No. 24554. 
9. Acs, Z.J., Groot, H.L.F., Nijkamp, P. (2002). Knowledge, Innovation and Regional Development. The Emergence of the Knowledge Economy, p. 1-14.

10.Investors (s.a.). Retrieved: http://www.rsez.Iv/index.php/en/about-us Access: 14.02.2019.

11. Education and Skills (s.a.). Organization for Economic Co-operation and Development countries. Retrieved: http://www.oecd.org/going-digital/topics/education-skills/ Access: 07.02.2019.

12. Regions And Cities At a Glance 2018 - Latvia (2018). Organization for Economic Co-operation and Development countries. Retrieved: https://www.oecd.org/cfe/LATVIA-Regions-and-Cities-2018.pdf Access: 07.02.2019.

13. Opinion Of The Innovation Union - transforming Europe into a post-crisis world (2011). Retrieved: http://www.europarl.europa.eu/meetdocs/2009_2014/documents/regi/ad/861/861338/861338lv.pdf Access: 12.02.2019. 